Article

\title{
Effect of Al-5Ti-C Master Alloy on the Microstructure and Mechanical Properties of Hypereutectic Al-20\%Si Alloy
}

\section{Wanwu Ding, Tiandong Xia *, Wenjun Zhao and Yangtao Xu}

School of Materials Science and Engineering, Lanzhou University of Technology, Lanzhou 730050, Gansu, China; E-Mails: dingww@lut.cn (W.D.); zhaowj@lut.cn (W.Z.); xuyat@sina.com (Y.X.)

* Author to whom correspondence should be addressed; E-Mail: xiatid@ sina.com;

Tel./Fax: +86-931-2914-173.

Received: 6 November2013; in revised form: 8 February 2014 / Accepted: 10 February 2014 /

Published: 14 February 2014

\begin{abstract}
Al}-5 \mathrm{Ti}-\mathrm{C}$ master alloy was prepared and used to modify hypereutectic Al-20\%Si alloy. The microstructure evolution and mechanical properties of hypereutectic Al-20\%Si alloy with Al-5Ti-C master alloy additions (0, 0.4, 0.6, 1.0, 1.6 and $2.0 \mathrm{wt} \%)$ were investigated. The results show that, Al-5Ti-C master alloy (0.6 wt $\%, 10 \mathrm{~min})$ can significantly refine both eutectic and primary Si of hypereutectic Al-20\%Si alloy. The morphology of the primary Si crystals was significantly refined from a coarse polygonal and star-like shape to a fine polyhedral shape and the grain size of the primary Si was refined from roughly $90-120 \mu \mathrm{m}$ to $20-50 \mu \mathrm{m}$. The eutectic Si phases were modified from a coarse platelet-like/needle-like structure to a fine fibrous structure with discrete particles. The Al-5Ti-C master alloy $(0.6 \mathrm{wt} \%, 30 \mathrm{~min})$ still has a good refinement effect. The ultimate tensile strength (UTS), elongation (El) and Brinell hardness (HB) of Al-20\%Si alloy modified by the Al-5Ti-C master alloy ( $0.6 \mathrm{wt} \%, 10 \mathrm{~min}$ ) increased by roughly $65 \%$, $70 \%$ and $51 \%$, respectively, due to decreasing the size and changing the morphology on the primary and eutectic Si crystals. The change in mechanical properties corresponds to evolution of the microstructure.
\end{abstract}

Keywords: Al-5Ti-C master alloy; hypereutectic Al-20\%Si alloy; modification; primary Si; eutectic $\mathrm{Si}$; mechanical properties 


\section{Introduction}

Hypereutectic Al-Si alloys have been widely investigated because of their excellent properties, which include excellent wear and corrosion resistance, high temperature strength, low coefficient of thermal expansion, good cast performance, and high specific strength [1-3]. Therefore, hypereutectic Al-Si alloys are widely used in aeronautic, astronautic, and automobile industries. It has been documented extensively that the microstructure of hypereutectic $\mathrm{Al}-\mathrm{Si}$ alloys, prepared by conventional casting routines, usually consist of a coarse primary silicon phase in a fibrous eutectic matrix [4-6]. The brittleness of the coarse Si crystals (both eutectic and primary silicon) is the main reason responsible for the poor properties of $\mathrm{Al}-\mathrm{Si}$ alloys because coarse silicon crystals lead to premature crack initiation and fracture in tension [7,8]. In order to refine the primary silicon, many methods have been carried out, such as high-pressure casting, the rapid solidification technique [9], and melt overheating treatment [10-12]. However, these processes are complex and difficult to control. The desired properties cannot be obtained or may even become worse. Microstructure control using minor element addition is the most popular method due to its simplicity and effectiveness. Phosphor is the most effective refinement element of primary Si in hypereutectic Al-Si alloy [13,14]. The size of primary Si particles can be refined to $20-30 \mu \mathrm{m}$ by adding minor amounts of phosphor. Because the phosphor has no modification effect on the eutectic $\mathrm{Si}$, the eutectic $\mathrm{Si}$ can still keep the large needle shape. Recently, attention has been given to the complex modification of primary and eutectic $\mathrm{Si}$ in order to significantly enhance the mechanical properties of hypereutectic Al-Si alloys. It has been documented that rare earth (RE) metal can modify the eutectic Si in hypereutectic Al-Si alloys $[15,16]$. The refinement of primary Si crystals was also obtained with the addition of rare earth elements $[17,18]$.

In recent years, $\mathrm{Al}-\mathrm{Ti}-\mathrm{B}$ and $\mathrm{Al}-\mathrm{Ti}-\mathrm{C}$ master alloys have been found to be good refiners for $\mathrm{Al}$ and its alloys [19-21]. Compared with $\mathrm{TiB}_{2}$ in $\mathrm{Al}-\mathrm{Ti}-\mathrm{B}$ master alloys, TiC particles in $\mathrm{Al}-\mathrm{Ti}-\mathrm{C}$ grain refiner as the heterogeneous nucleation core have a smaller aggregation tendency which is not affected by such elements as $\mathrm{Zr}, \mathrm{Cr}, \mathrm{Mn}$ and $\mathrm{V}$. Therefore, more attention has been paid to the preparation, microstructure and performance of Al-Ti-C master alloys [19,22,23]. Recently, Sagstad [24] synthesized Al-Ti-B-Sr master alloys, combining grain refiners and modifiers together. It has also been reported that $\mathrm{B}$ and $\mathrm{Sr}$ have an adverse effect on grain refinement and modification because of the formation of a $\mathrm{SrB}_{6}$ compound [25], resulting in a mutual poisoning effect. Zhao [26] prepared $\mathrm{Al}-\mathrm{Ti}-\mathrm{C}-\mathrm{Sr}$ master alloys and reported that satisfactory grain refining and modifying effects were obtained by the addition of Al-Ti-C-Sr alloys (0.5 wt\%) to the A356 alloy. However, little has been reported on the microstructure and mechanical properties of hypereutectic Al-20\%Si alloy with the addition of Al-Ti-C master alloy. In this study, Al-5Ti-C master alloy was prepared and adopted to modify hypereutectic $\mathrm{Al}-20 \% \mathrm{Si}$ alloy with the aim of investigating the effect of Al-5Ti-C master alloy on the microstructure of hypereutectic Al-20\%Si alloy. At the same time, the mechanical properties and hardness of the hypereutectic Al-20\%Si alloy were also studied. 


\section{Results and Discussion}

\subsection{Microstructures of Al-5Ti-C Alloy}

Figure 1 shows the XRD (X-ray diffraction) pattern of the Al-5Ti-C alloys. As can be seen from Figure 1, Al-5Ti-C alloy is composed of $\mathrm{Al}, \mathrm{TiAl}_{3}$ and $\mathrm{TiC}$. Figure $2 \mathrm{a}$ shows the $\mathrm{OM}$ picture of the $\mathrm{Al}-5 \mathrm{Ti}-\mathrm{C}$ alloy. As we can see from Figure $2 \mathrm{a}$, on the $\mathrm{Al}$ substrate of $\mathrm{Al}-5 \mathrm{Ti}-\mathrm{C}$ alloy a large number of strip-like or lump-like substances are uniformly distributed with a size of roughly $20-55 \mu \mathrm{m}$ in length and $8-12 \mu \mathrm{m}$ in width as well as small black particles. Figure $2 \mathrm{~b}, \mathrm{c}$ show the SEM image of the strip-like substances and that of the small black particles. Table 1 shows the analysis result of the energy spectrum of the chemical composition of point A in lump-like substances and point B in small particles in Figure 2. From Table 1, we can see that at point $\mathrm{A}$ in the strip-like substances, the molar mass fraction of element $\mathrm{Al}$ is $69.72 \%$, the molar mass fraction of element $\mathrm{Ti}$ is $21.85 \%$, and the molar mass ratio between element $\mathrm{Al}$ and element $\mathrm{Ti}$ is 3.19. At point $\mathrm{B}$ in the small particles, the molar mass fraction of element $\mathrm{C}$ is $27.98 \%$, the molar mass fraction of element $\mathrm{Ti}$ is $25.52 \%$, and the molar mass ratio between element $\mathrm{C}$ and element $\mathrm{Ti}$ is 1.1. According to the analysis results of the XRD pattern of $\mathrm{Al}-5 \mathrm{Ti}-\mathrm{C}$ alloy, we can see that the strip-like substances in Figure $2 \mathrm{~b}$ are $\mathrm{TiAl}_{3}$, and the small black particles in Figure $2 \mathrm{c}$ are TiC. From the above analysis, we know that in the Al-5Ti-C alloys used in the experiment a large number of strip-like or lump-like $\mathrm{TiAl}_{3}$ and $\mathrm{TiC}$ particles are contained, distributed in a dispersed and uniform way.

Figure 1. XRD pattern of $\mathrm{Al}-5 \mathrm{Ti}-\mathrm{C}$ master alloy.

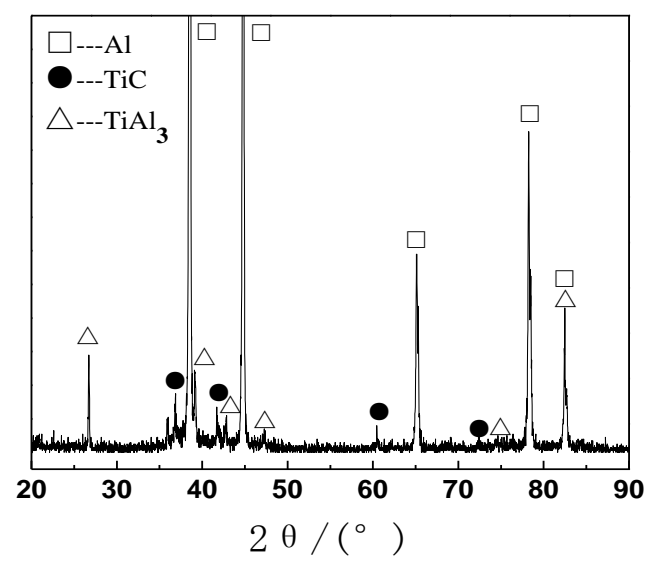

Figure 2. Microstructures of Al-5Ti-C alloy: (a) optical microscopy (OM) image; (b) scanning electron microscopy (SEM) image of $\mathrm{TiAl}_{3}$; and (c) SEM image of TiC.

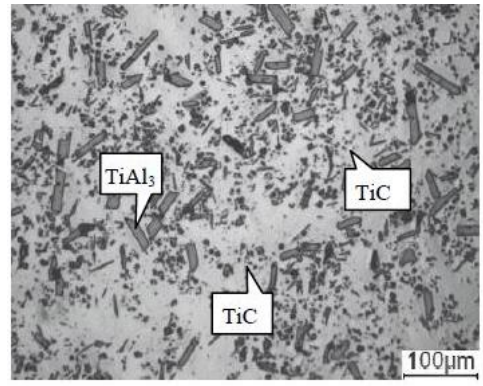

(a)

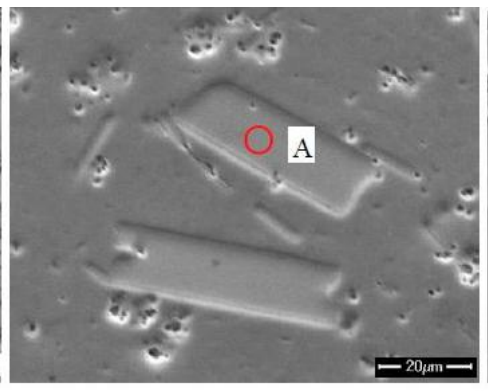

(b)

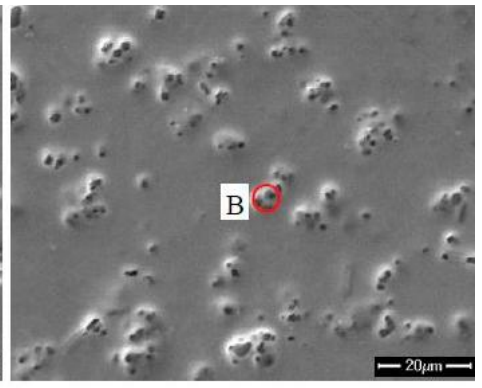

(c) 
Table 1. EDS composition analysis of point A and point B in Figure 2.

\begin{tabular}{cccc}
\hline Point No. & $\boldsymbol{x}(\mathrm{Al}) / \boldsymbol{\%}$ & $\boldsymbol{x}(\mathrm{Ti}) / \boldsymbol{\%}$ & $\boldsymbol{x}(\mathbf{C}) / \boldsymbol{\%}$ \\
\hline A & 69.72 & 21.85 & 8.43 \\
B & 46.50 & 25.52 & 27.98 \\
\hline
\end{tabular}

\subsection{Microstructure Studies of Modified and Unmodified Al-20\%Si Alloys}

Figure 3 shows the optical micrographs of hypereutectic Al-20\%Si alloy with various concentrations of $\mathrm{Al}-5 \mathrm{Ti}-\mathrm{C}$ alloy, which demonstrates a substantial difference in microstructure of the size and morphology of the primary Si crystals. Figure $3 \mathrm{a}$ shows the optical micrograph of hypereutectic $\mathrm{Al}-20 \% \mathrm{Si}$ alloy without addition of $\mathrm{Al}-5 \mathrm{Ti}-\mathrm{C}$ alloy. It is clearly seen from Figure $3 \mathrm{a}$ that the primary Si crystals are present in the form of coarse polygonal shape and star-like shapes, and the average size of primary Si crystals is up to roughly $104 \mu \mathrm{m}$. Figure $3 \mathrm{~b}$ presents the microstructure of $\mathrm{Al}-20 \% \mathrm{Si}$ alloy inoculated with $0.4 \% \mathrm{Al}-5 \mathrm{Ti}-\mathrm{C}$ alloy. It is obvious that the coarse star-shaped primary $\mathrm{Si}$ phase is completely absent, and the average size of primary $\mathrm{Si}$ decreases to less than roughly $54 \mu \mathrm{m}$. Figure $3 \mathrm{c}$ shows the microstructure of $\mathrm{Al}-20 \% \mathrm{Si}$ alloy containing Al-5Ti-C alloy, at levels of $0.6 \%$. It is obvious that the edges and angles of most of the primary Si are passivated, and the average size of the primary $\mathrm{Si}$ further decreases to roughly $39 \mu \mathrm{m}$, with fine primary $\mathrm{Si}$ homogeneously distributed in the $(\alpha-\mathrm{Al}+\mathrm{Si})$ eutectic matrix. However, when the addition of $\mathrm{Al}-5 \mathrm{Ti}-\mathrm{C}$ alloy was further increased to $1.0 \%, 1.6 \%$ and $2.0 \%$, the average size of primary Si crystals increased to roughly 50, 59 and $66 \mu \mathrm{m}$, respectively, as shown in Figure $3 \mathrm{~d}-\mathrm{f}$.

The effect of Al-5Ti-C alloy on the morphology of eutectic Si is shown in SEM micrographs in Figure 4. Figure 4a shows the SEM micrograph of the eutectic Si structure in Al-20\%Si alloy without addition of Al-5Ti-C alloy, which reveals coarse needles and platelets of eutectic $\mathrm{Si}$ in the metal matrix. Figure $4 \mathrm{~b}$ represents the microstructure of $\mathrm{Al}-20 \% \mathrm{Si}$ alloy with addition of $0.4 \% \mathrm{Al}-5 \mathrm{Ti}-\mathrm{C}$ alloy. It can be clearly observed that the size and inter-flake spacing of eutectic Si significantly decreases with the addition of Al-5Ti-C alloy. Moreover, the coarse acicular and plate-like eutectic Si structure was transformed into a branched morphology, and the edges and corners of the eutectic Si became smooth and round. Figure 4c shows the microstructure of eutectic Si in Al-20\%Si alloy with the addition of $0.6 \% \mathrm{Al}-5 \mathrm{Ti}-\mathrm{C}$ alloy. It is apparent that most of the eutectic Si structure changed to a fine fibrous structure with discrete particles. However when the addition of Al-5Ti-C alloy was further increased to $1.0 \%, 1.6 \%$ and $2.0 \%$, the average size of the eutectic Si crystals increased and the morphology of the eutectic Si structure was transformed into a coral-like fibrous structure with coarse needles and platelets, as shown in Figure 4d,f.

Figure 5 shows the relation curve between the content of $\mathrm{Al}-5 \mathrm{Ti}-\mathrm{C}$ master alloy and the size of primary $\mathrm{Si}$ and eutectic $\mathrm{Si}$ of $\mathrm{Al}-20 \% \mathrm{Si}$ alloys. It can be seen that when the addition amount of $\mathrm{Al}-5 \mathrm{Ti}-\mathrm{C}$ master alloy is less than $0.6 \mathrm{wt} \%$, the primary $\mathrm{Si}$ and eutectic $\mathrm{Si}$ in the hypereutectic $\mathrm{Al}-20 \% \mathrm{Si}$ alloy is in the less deterioration state; when the amount of Al-5Ti-C master alloy added is more than $0.6 \mathrm{wt} \%$, the primary $\mathrm{Si}$ and eutectic $\mathrm{Si}$ in the hypereutectic $\mathrm{Al}-20 \% \mathrm{Si}$ alloy is in the over deterioration state; with regard to less deterioration, we think it is due to an insufficient amount of modifier added. For over deterioration, it may be that the $\mathrm{TiC}$ and $\mathrm{TiAl}_{3}$ added in the alloy melt interact with other alloying elements in the melt and form new compounds, so that the effective content of 
modifier in the alloy melt is decreased, which finally results in inadequate deterioration. The results show that $0.6 \% \mathrm{Al}-5 \mathrm{Ti}-\mathrm{C}$ alloy cannot only effectively decrease the size of primary $\mathrm{Si}$ and eutectic $\mathrm{Si}$ crystals in hypereutectic Al-20\%Si alloy, but it can also change the morphology of primary Si and eutectic Si crystals.

Figure 3. Optical micrographs of primary Si crystals in hypereutectic Al-20\%Si alloy: (a) unmodified; (b) $0.4 \mathrm{wt} \% \mathrm{Al}-5 \mathrm{Ti}-\mathrm{C}$; (c) $0.6 \mathrm{wt} \% \mathrm{Al}-5 \mathrm{Ti}-\mathrm{C}$; (d) $1.0 \mathrm{wt} \% \mathrm{Al}-5 \mathrm{Ti}-\mathrm{C}$; (e) $1.6 \mathrm{wt} \% \mathrm{Al}-5 \mathrm{Ti}-\mathrm{C}$; and (f) $2.0 \mathrm{wt} \% \mathrm{Al}-5 \mathrm{Ti}-\mathrm{C}$.

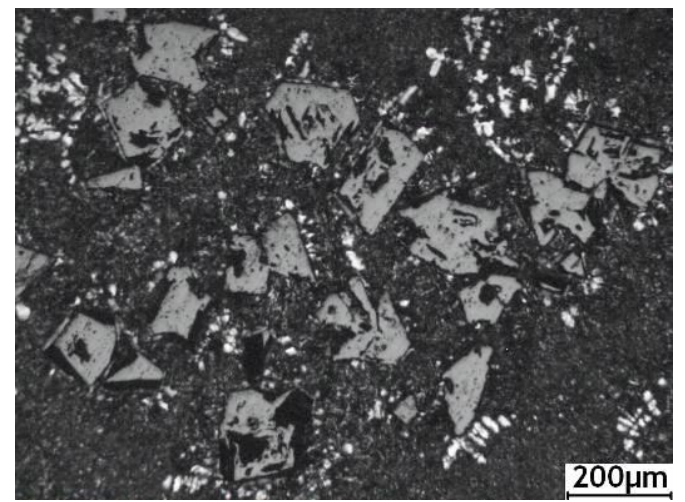

(a)

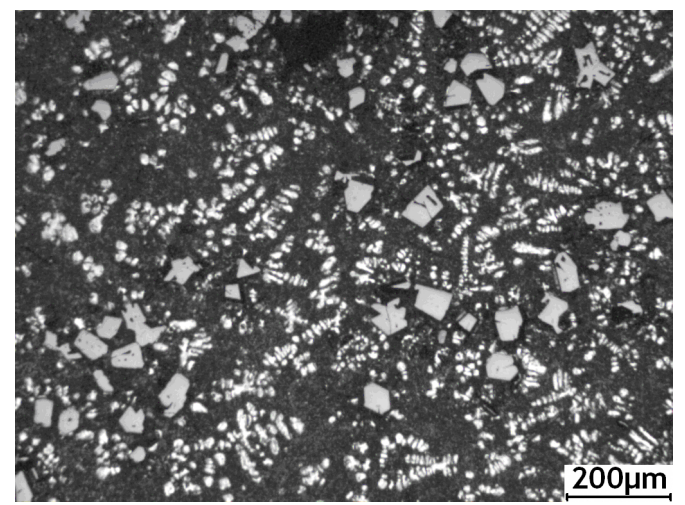

(c)

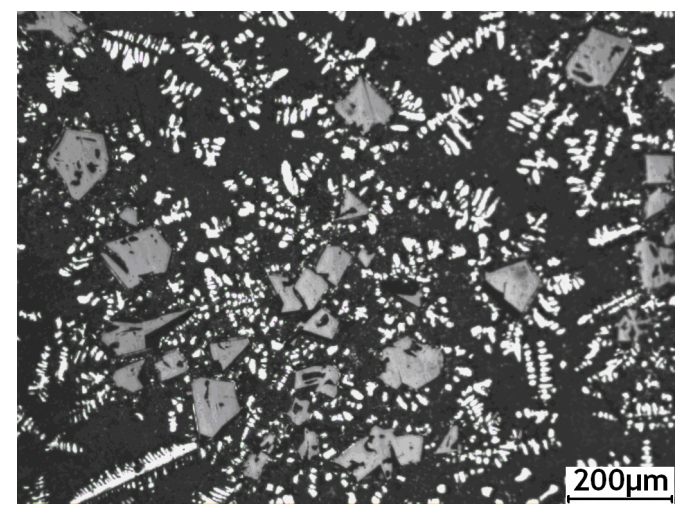

(e)

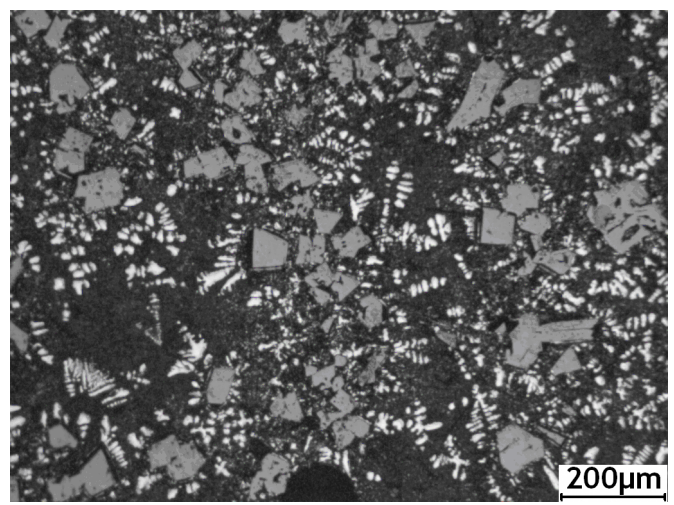

(b)

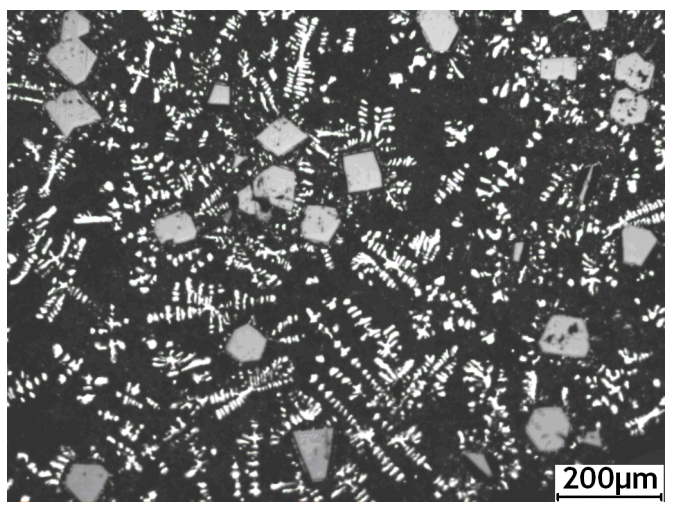

(d)

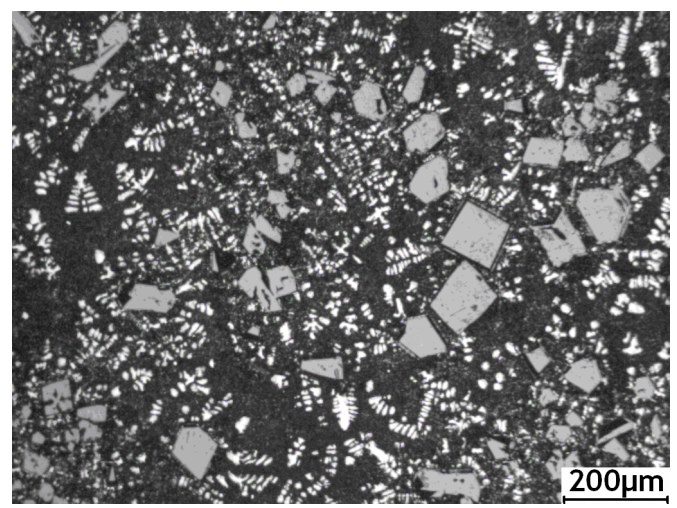

(f) 
Figure 4. SEM images of eutectic $\mathrm{Si}$ crystals in hypereutectic Al-20\% $\mathrm{Si}$ alloy: (a) unmodified; (b) $0.4 \mathrm{wt} \%$ Al-5Ti-C; (c) $0.6 \mathrm{wt} \% \mathrm{Al}-5 \mathrm{Ti}-\mathrm{C}$; (d) $1.0 \mathrm{wt} \% \mathrm{Al}-5 \mathrm{Ti}-\mathrm{C}$; (e) $1.6 \mathrm{wt} \% \mathrm{Al}-5 \mathrm{Ti}-\mathrm{C}$; and (f) $2.0 \mathrm{wt} \% \mathrm{Al}-5 \mathrm{Ti}-\mathrm{C}$.

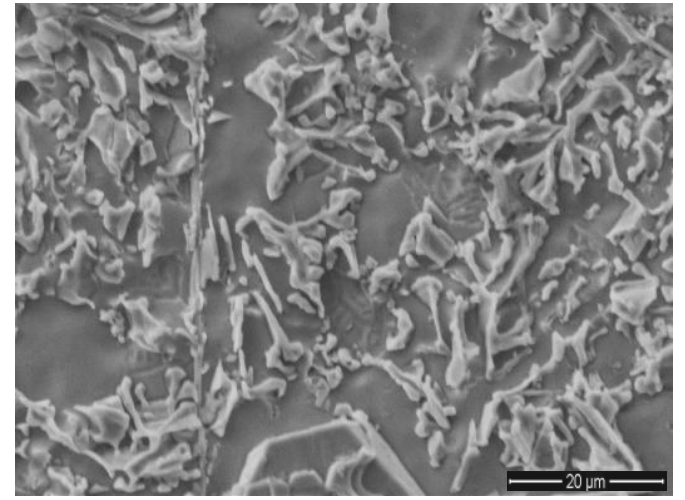

(a)

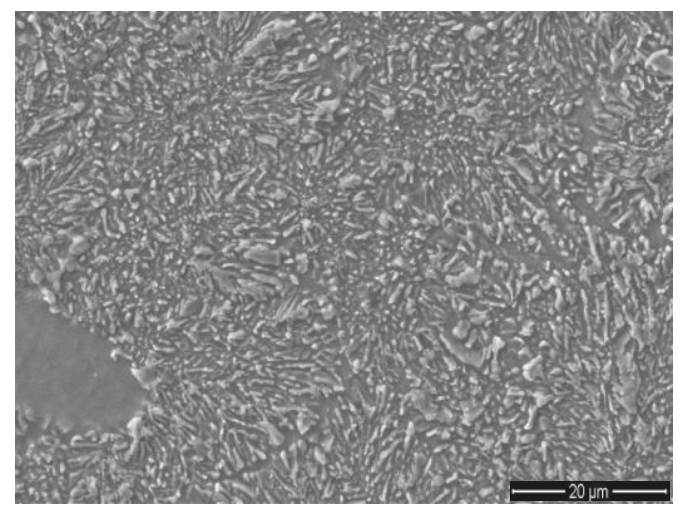

(c)

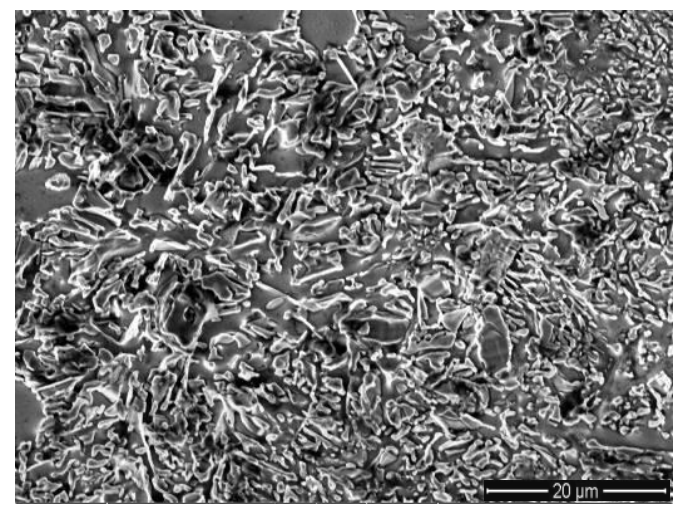

(e)

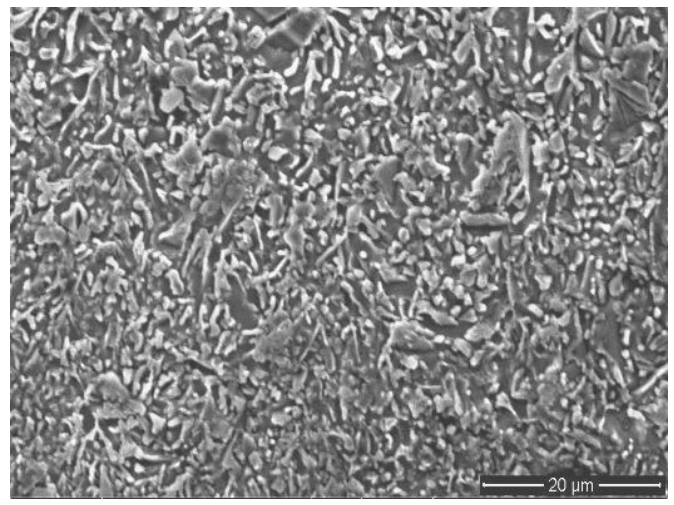

(b)

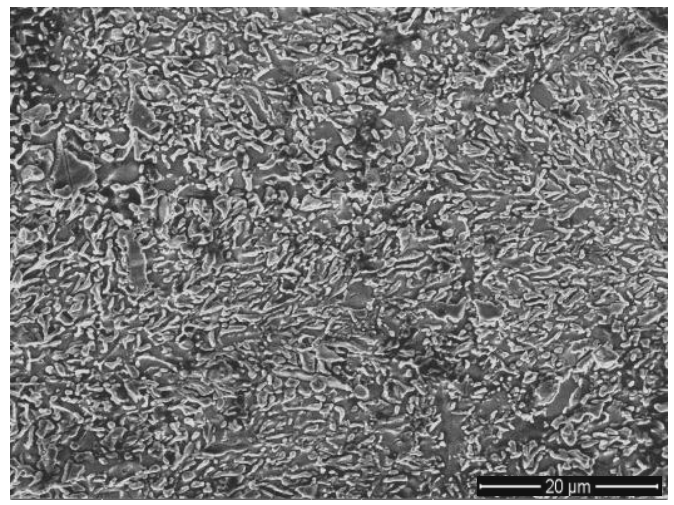

(d)

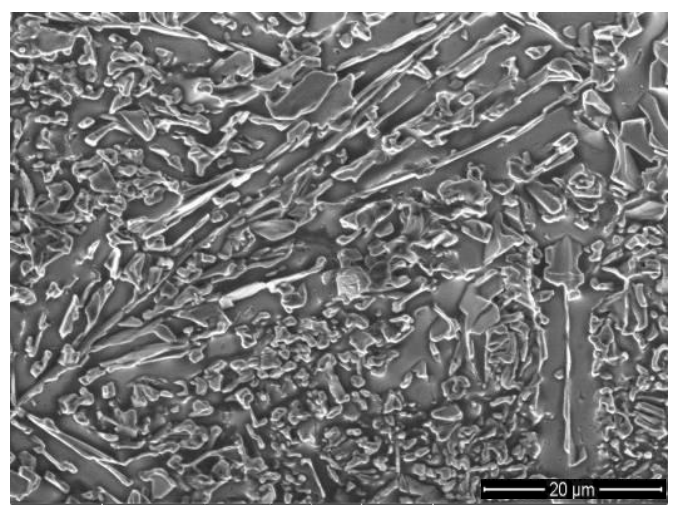

(f)

Figures 6 and 7 show the microstructures of the Al-20\% Si alloy in which Al-5Ti-C master alloy, whose mass fraction is $0.6 \%$, is added and is then heat preserved for different times. As can be seen, the deterioration effect of $\mathrm{Al}-5 \mathrm{Ti}-\mathrm{C}$ master alloy on the primary $\mathrm{Si}$ and eutectic $\mathrm{Si}$ in the hypereutectic Al-20\% Si alloy varies with the heat treatment time. Figure 8 shows the relationship curve between the average size of the primary Si and eutectic Si in the hypereutectic Al-20 wt\% Si alloy and different heat treatment times of refinement and deterioration. It can be seen that when the heat treatment time is $30 \mathrm{~min}$, the average size of primary $\mathrm{Si}$ is roughly $41 \mu \mathrm{m}$ (Figure 6a), and the size of eutectic Si is roughly $2-3 \mu \mathrm{m}$ (Figure $7 \mathrm{a}$ ). With the increase in heat treatment time of refinement and deterioration, 
the sizes of primary $\mathrm{Si}$ and eutectic $\mathrm{Si}$ in the alloy increase gradually. When the heat treatment time is $120 \mathrm{~min}$, the morphology of primary Si is again changed into a coarse and complex picture (Figure 6d), while the eutectic Si is changed from ball-shaped or short-rod-like structures into long needle-like ones (Figure 7d).

Figure 5. The relation curve between the content of $\mathrm{Al}-5 \mathrm{Ti}-\mathrm{C}$ and the average size of primary Si and eutectic Si in hypereutectic Al-20\%Si alloy.

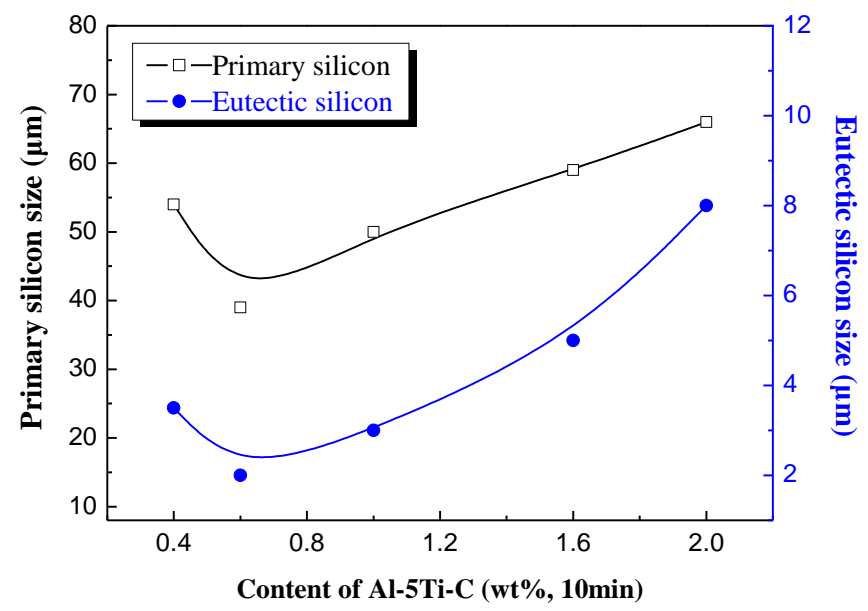

Figure 6. Optical micrographs of primary Si crystals in hypereutectic Al-20\%Si alloy with $0.6 \mathrm{wt} \% \mathrm{Al}-5 \mathrm{Ti}-\mathrm{C}$ master alloy at different heat treatment times: (a) $30 \mathrm{~min}$; (b) $60 \mathrm{~min}$; (c) $90 \mathrm{~min}$; and (d) $120 \mathrm{~min}$.

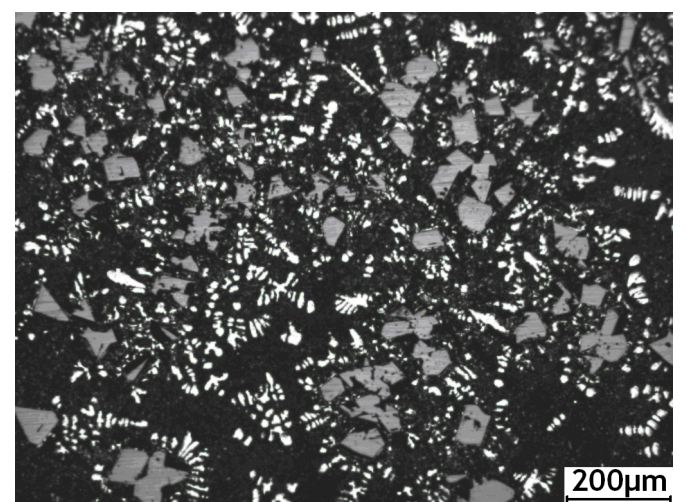

(a)

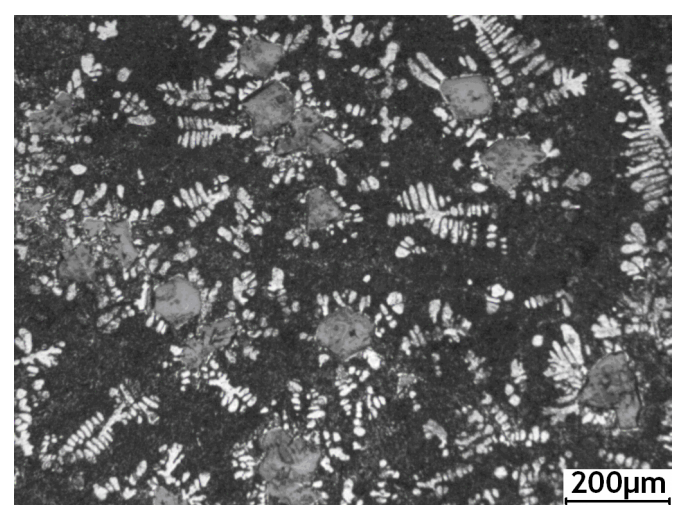

(c)

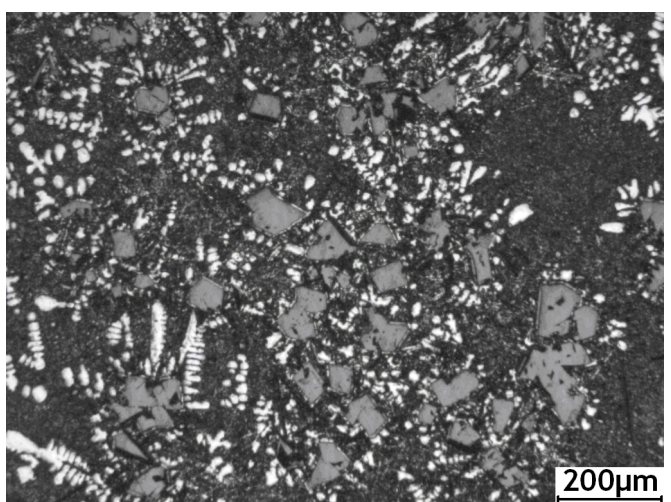

(b)

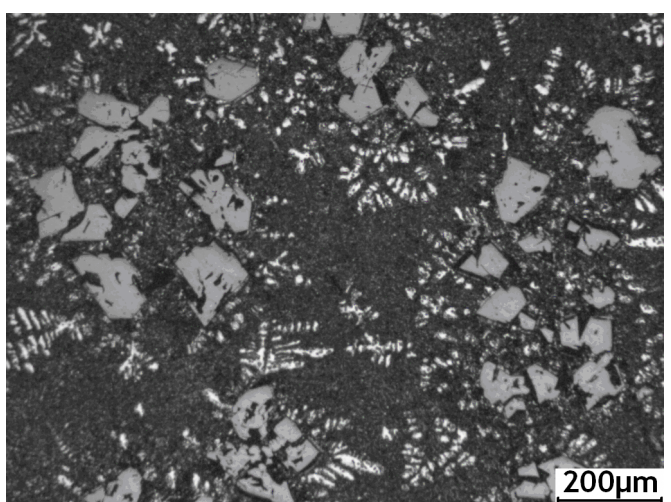

(d) 
Figure 7. SEM images of eutectic Si crystals in hypereutectic Al-20\%Si alloy with $0.6 \mathrm{wt} \% \mathrm{Al}-5 \mathrm{Ti}-\mathrm{C}$ master alloy at different heat treatment times: (a) $30 \mathrm{~min}$; (b) $60 \mathrm{~min}$; (c) $90 \mathrm{~min}$; and (d) $120 \mathrm{~min}$.

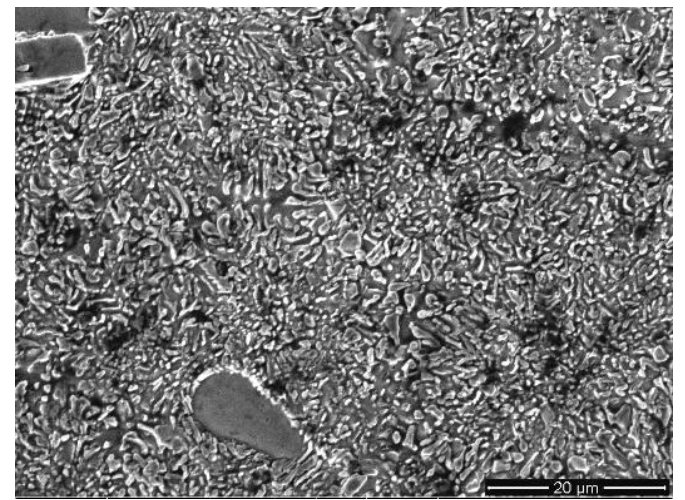

(a)

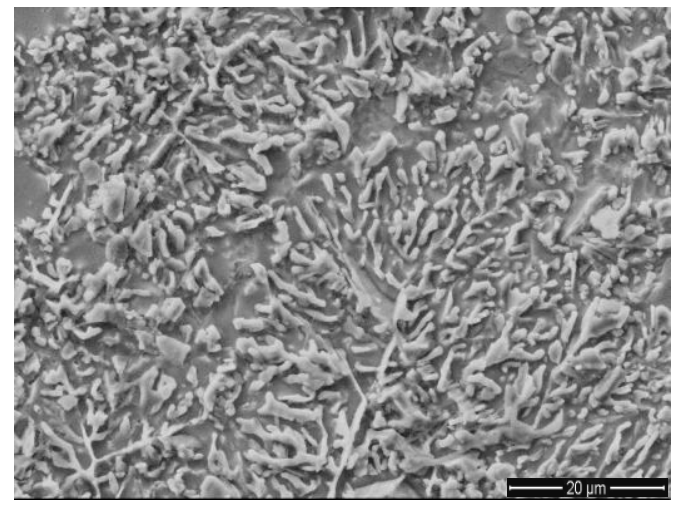

(c)

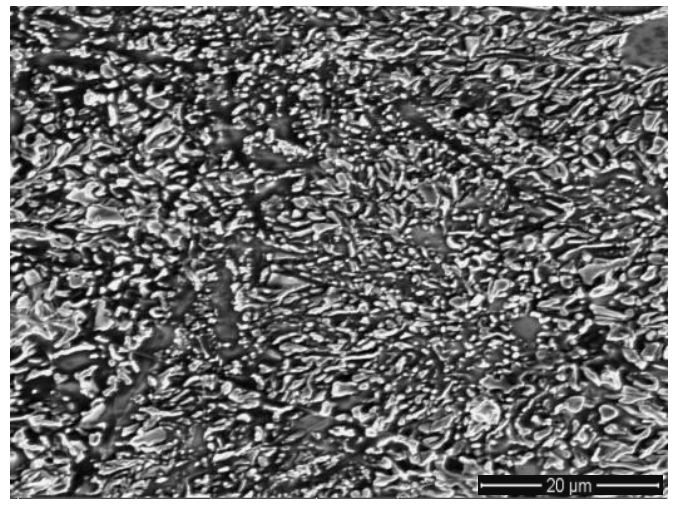

(b)

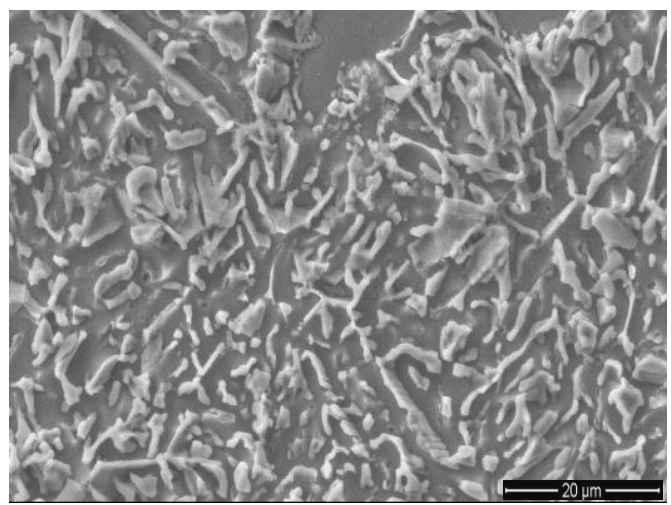

(d)

Figure 8. The relation curve between holding time and the size of primary Si and eutectic $\mathrm{Si}$ in hypereutectic Al-20\%Si alloy with $0.6 \mathrm{wt} \% \mathrm{Al}-5 \mathrm{Ti}-\mathrm{C}$ master alloy.

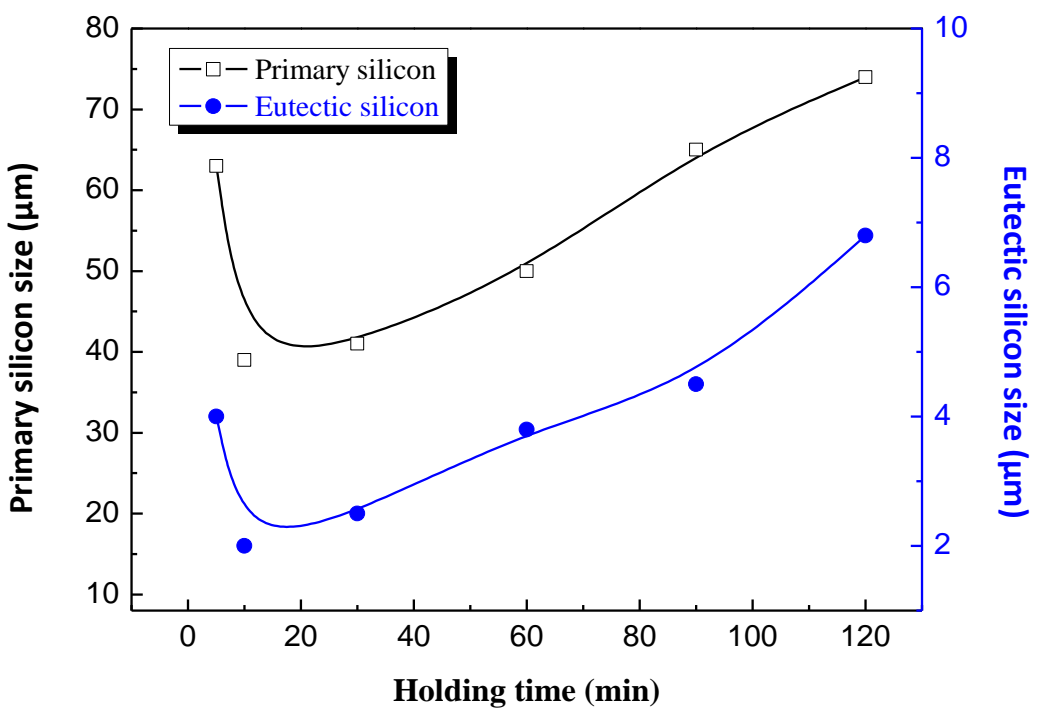

Barerji and Reif [27] from Berlin University indicated that since $\mathrm{TiAl}_{3}$ is thermodynamically unstable, it will be dissolved in liquid aluminum at a speed of $40 \mu \mathrm{m} / \mathrm{min}$. López experimentally found that when the temperature of $\mathrm{Al}-\mathrm{Si}$ alloy is higher than $600{ }^{\circ} \mathrm{C}$, the $\mathrm{TiC}$ in the alloy decomposes, and 
decomposition of $\mathrm{TiC}$ in the $\mathrm{Al}-\mathrm{Si}$ alloy is achieved through continuous diffusion of $\mathrm{Ti}$ and $\mathrm{C}$ into the alloy [28]. In this experiment, when Al-5Ti-C master alloy was added into hypereutectic Al-20 wt\% Si alloy, after being heat preserved for $10 \mathrm{~min}$, the full decomposition of $\mathrm{TiAl}_{3}$ and $\mathrm{TiC}$ particles occurred, which thus provides sufficient amount of $\mathrm{Ti}$ atoms for the aluminum melt. The dissolution of $\mathrm{TiAl}_{3}$ causes an equilibrium of dissolved $\mathrm{Ti}$ in the bulk melt. It results in the establishment of an activity gradient which leads to solute segregation, and the well-known contact time in grain refining practice is a result of this process [29]. Whenever an element is exposed to an activity gradient, there is a tendency to undergo net transport [30]. Thus, Ti atoms congregate at the growing surface of the primary Si and eutectic Si based on the activity gradient of Ti. During the solidification of the alloy melt, the Ti-rich zone is easy to form on the growing Si surface. The Ti-rich layer will prevent the Si atoms in the melt from diffusing toward the growing surface of primary $\mathrm{Si}$ and eutectic Si, thereby inhibiting the growth of primary $\mathrm{Si}$ and eutectic $\mathrm{Si}$, and thus indirectly refining them. However, as the heat treatment time increases, when $\mathrm{Ti}$ atoms concentrate to a certain degree in these areas and exceed their saturation value, the Ti-rich layer will change into $\mathrm{TiAl}_{3}$ [31,32], thus losing the inhibition effect of primary $\mathrm{Si}$ and eutectic $\mathrm{Si}$, and leading to recession of the refinement and deterioration effect. The refinement mechanism of $\mathrm{Al}$ alloy is extremely complicated, and it is also very difficult to fully analyze the refinement process and mechanism of Al-Ti-C toward Al-20\% Si alloy.

\subsection{Analyses of Mechanical Properties}

Figure 9 shows typical ultimate tensile strength (UTS) and elongation (El) with different levels of $\mathrm{Al}-5 \mathrm{Ti}-\mathrm{C}$ master alloy. It is evident that the ultimate tensile strength (UTS) is enhanced by roughly $65 \%$ from 91 to $150 \mathrm{MPa}$, and elongation is increased by roughly $70 \%$ from $0.37 \%$ to $0.63 \%$ after the addition of $0.6 \% \mathrm{Al}-5 \mathrm{Ti}-\mathrm{C}$ master alloy. A further increase in the amount of addition of Al-5Ti-C master alloy up to $1.0 \%$ leads to a decrease in both UTS and El. The results are in agreement with the aforementioned images (Figures 3 and 4). The mechanical properties of hypereutectic Al-20\%Si alloy mainly depend on the morphology and size of primary Si and eutectic Si crystals. It has been reported that the cracks easily initiate from the stiff and brittle primary Si as well as eutectic Si crystals [3]. On the other hand, the cracks may come from debonding of Si particles, and then propagate through the boundaries with the $\alpha$-Al phase [15]. Therefore, both UTS and El significantly improve when primary and eutectic Si phases are modified by adding Al-5Ti-C master alloy due to decreasing or eliminating premature crack initiation and fracture in tension.

Figure 10 shows that the ingot cast without any mould coating has the lowest hardness value. However, as $\mathrm{Al}-5 \mathrm{Ti}-\mathrm{C}$ master alloy was introduced into the mould coating and its concentrations progressively increased from 0 to $0.6 \mathrm{wt} \%$, the hardness value increased by roughly $51 \%$ from 93 to $141 \mathrm{HB}$. Above $0.6 \mathrm{wt} \% \mathrm{Al}-5 \mathrm{Ti}-\mathrm{C}$ master alloy concentration the hardness value decreased. This shows that the optimum value of $\mathrm{Al}-5 \mathrm{Ti}-\mathrm{C}$ master alloy in alumina based mould wash which gives us the maximum hardness value (HB141) is $0.6 \mathrm{wt} \%$. It is expected that the hardness may depend on the grain size of the Si phase following the Hall-Petch type equation [33,34]:

$$
H=H_{0}+K_{H} D^{-\frac{1}{2}}
$$


where $H$ is the hardness, $H_{0}$ is the hardness expected at a hypothetical infinite grain size, $K_{H}$ is a constant, and $D$ is the average grain diameter. The result causes the Brinell hardness of the modified Al-Si alloys to be higher than that of the unmodified Al-20\%Si alloys.

Figure 9. Mechanical properties of hypereutectic Al-20\% Si alloy with various contents of Al-5Ti-C master alloy.

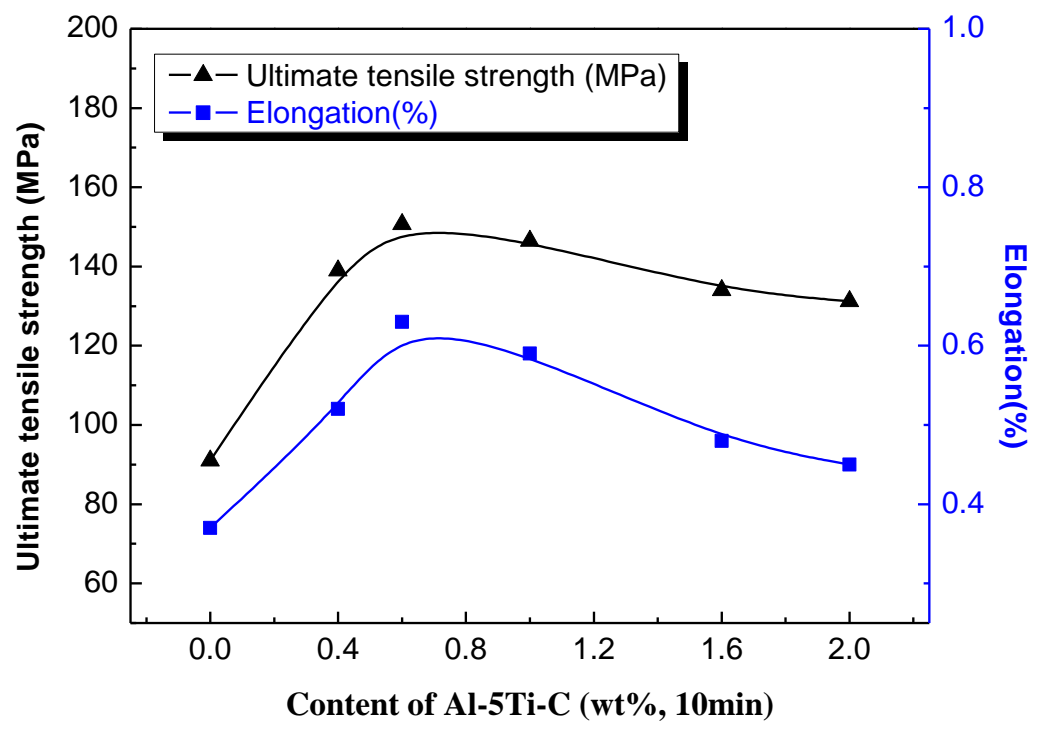

Figure 10. Brinell hardness of hypereutectic Al-20\%Si alloy with various contents of Al-5Ti-C master alloy.

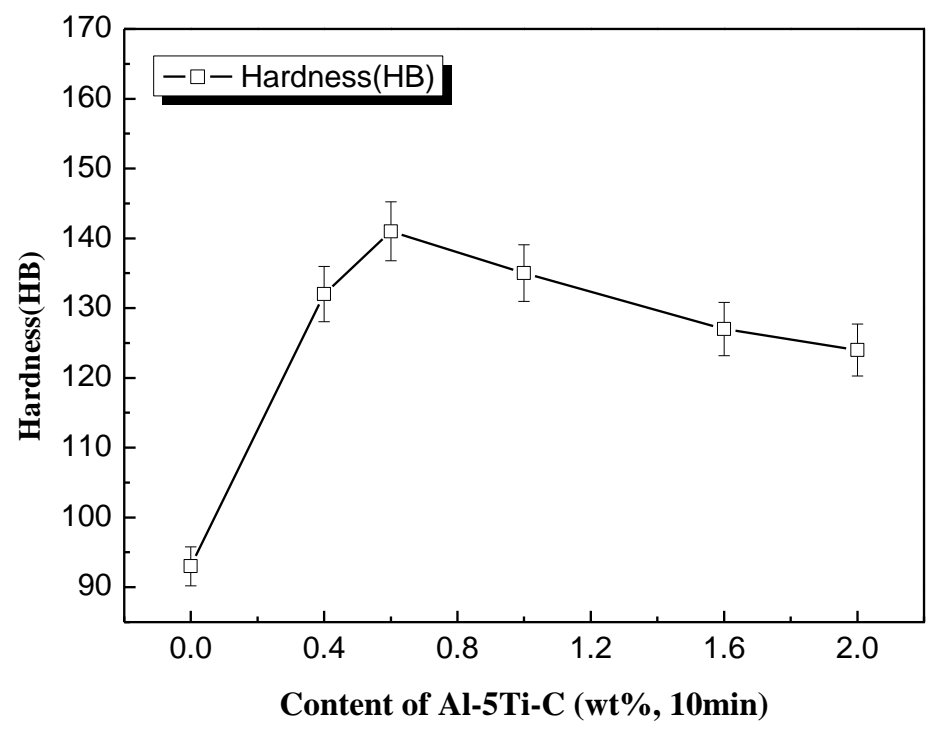

\section{Experimental Section}

The main materials used in the experiments included: Al powder (99.6\%), Ti powder (99.3\%), $\mathrm{C}$ powder $(99.8 \%)$ and commercially pure aluminum. The main raw materials were made through ball mixing and cold pressing into prefabricated blocks. The prefabricated blocks went through a thermal explosion reaction in the pure molten aluminum at a temperature of $780{ }^{\circ} \mathrm{C}$ [35]. Analysis was conducted on the phase composition, microstructure morphology and components of the alloy with 
RigakuD/max-A X-ray diffract meter (XRD, PW 3040/60, PANalytical, Rotterdam, Holland), large optical microscope (MEF3) and the JSM-7500 scanning electron microscope (SEM, SSX-550 fitted with EDS equipment, Shimadzu Corporation, Kyoto, Japan).

The $0.5 \mathrm{~kg}$ hypereutectic $\mathrm{Al}-20 \% \mathrm{Si}$ (all percentages are wt $\%$ unless otherwise stated) alloy used in the experiment was melted in an electrical resistance furnace. The melt was brought to a temperature of $750{ }^{\circ} \mathrm{C}$ and degassed using a commercial degasser of solid hexachloroethane $\left(\mathrm{C}_{2} \mathrm{Cl}_{6}\right)$. Subsequently, the different additions of $\mathrm{Al}-5 \mathrm{Ti}-\mathrm{C}$ master alloy $(0.4 \%, 0.6 \%, 1.0 \%, 1.6 \%$ and $2.0 \%)$ were added to the alloy at $750{ }^{\circ} \mathrm{C}$, stirred and held for $10 \mathrm{~min}$ to ensure homogeneity of composition. Al-5Ti-C master alloy $(0.6 \mathrm{wt} \%)$ was added to the alloy, stirred and held for 30, 60, 90 and $120 \mathrm{~min}$ at $750{ }^{\circ} \mathrm{C}$. After the slag of the melt was skimmed, the melt was poured into a preheated (about $200{ }^{\circ} \mathrm{C}$ ) permanent steel mould (20 mm in inner diameter and $50 \mathrm{~mm}$ in length) at $720{ }^{\circ} \mathrm{C}$. Microstructural survey of samples was conducted with optical microscopy (OM) and scanning electron microscopy (SEM) after preparing samples according to standard metallographic procedures, which were etched using Keller's reagent $\left(2.5 \mathrm{~mL} \mathrm{HNO}_{3}, 1.5 \mathrm{~mL} \mathrm{HCl}, 1 \mathrm{~mL} \mathrm{HF}\right.$, and $95 \mathrm{~mL} \mathrm{H}_{2} \mathrm{O}$ ). The unmodified ingot was obtained under the same procedure without adding Al-5Ti-C master alloy. The average value of Brinell hardness was taken and tensile tests were carried out on MTS810 from five measurements.

\section{Conclusions}

Al-5Ti-C master alloy was prepared and the effect of different quantities of Al-5Ti-C master alloy on the microstructure and mechanical properties of $\mathrm{Al}-20 \% \mathrm{Si}$ alloy was studied. The following conclusions were drawn:

(i) Al-5Ti-C master alloy with a more uniform microstructure was successfully prepared through a method of liquid solidification reactions, composed of $\mathrm{Al}, \mathrm{TiAl}_{3}$ and $\mathrm{TiC}$.

(ii) Al-5Ti-C master alloy can significantly refine primary Si crystals such that their sizes decrease from roughly $90-120$ to 20-50 $\mu \mathrm{m}$ and the morphology changes from a coarse star-like and polygonal shape to a fine blocky shape at a concentration of $0.6 \% \mathrm{Al}-5 \mathrm{Ti}-\mathrm{C}$ alloy while being held for $10 \mathrm{~min}$.

(iii) Al-5Ti-C master alloy can obviously modify the eutectic Si structure and cause a transition from the coarse flake-like and acicular shape to a fine fibrous structure with discrete particles at a concentration of $0.6 \% \mathrm{Al}-5 \mathrm{Ti}-\mathrm{C}$ alloy while being held for $10 \mathrm{~min}$.

(iv) When the concentration of $\mathrm{Al}-5 \mathrm{Ti}-\mathrm{C}$ master alloy is $0.6 \%$, with increasing heat treatment time up to $30 \mathrm{~min}$, the Al-5Ti-C master alloy still undergoes a good modified effect.

(v) Due to the refinement and modification of primary and eutectic Si crystals, the ultimate tensile strength (UTS), elongation (El) and Brinell hardness (HB) are significantly improved on increasing the concentration of $\mathrm{Al}-5 \mathrm{Ti}-\mathrm{C}$ master alloy up to $0.6 \%$, in which the ultimate tensile strength increases by roughly $65 \%$, the elongation increases by roughly $70 \%$ and the Brinell hardness increases by roughly $51 \%$.

\section{Acknowledgments}

This research was financially supported by the National Natural Science Foundation of China (No. 50965012). The authors would like to acknowledge the financial support of the Natural Science Foundation of Gansu Province in China (Grant No. 1308RJYA088; 1308RJZA291). 


\section{Conflicts of Interest}

The authors declare no conflict of interest.

\section{References}

1. Timmermans, G.; Froyen, L. Fretting wear behaviour of hypereutectic $\mathrm{P} / \mathrm{M} \mathrm{Al}-\mathrm{Si}$ in oil environment. Wear 1999, 230, 105-117.

2. Ott, R.D.; Blue, C.A.; Santella, M.L.; Blau, P.J. The influence of a heat treatment on the tribological performance of a high wear resistant high Si Al-Si alloy weld overlay. Wear 2001, 250-251, 868-874.

3. Yilmaz, F.; Elliott, R. Microstructure and mechanical properties of unidirectionally solidified Al-Si alloys. J. Mater. Sci. 1989, 24, 2065-2070.

4. Zhang, D.; Yi, H.K.; Lu, W.J.; Fan, T.X. Influence of La on microstructure of hypereutectic Al-Si alloys. Trans. Nonferrous Met. Soc. China 2003, 13, 541-545.

5. Kuroishi, N.; Oani, Y.; Takeda, Y. High strength, high wear resistance aluminum-silicon PM alloys. Met. Powder Rep. 1985, 40, 642-645.

6. Jeong, H.G.; Yoon, D.J.; Kim, E.Z.; Park, H.J.; Nak, H. The influence by hydrostatic extrusion on the microstructure and extrudability of the IM processed hypereutectic Al-Si-X alloys. J. Mater. Process. Technol. 2002, 20, 438-443.

7. Sano, H. Spray formed aluminum alloy finds engine role. Met. Powder Rep. 1994, 49, 26-31.

8. Yamauchi, I.; Ohnaka, I.; Kawamoto, S.; Fukusako, T. Hot extrusion of rapidly solidified Al-Si alloy powder by the rotation-water-atomization process. Trans.Met. Inst. Jpn. 1986, 27,195-203.

9. Li, S.S.; Zhao, A.M.; Mao, W.M.; Zhong, X.Y. Mechanical properties of hypereutectic Al-Si alloy by semisolid processing. Trans. Nonferrous Met. Soc. China 2000, 10, 441-444.

10. Estrada, J.L.; Auszczyk, J. Characteristics of rapidly solidified Al-Si-X powders for high-performance application. J. Mater. Sci. 1990, 2, 886-904.

11. Wang, J.; He, S.X.; Sun, B.D.; Guo, Q.X. Grain refinement of Al-Si alloy (A356) by melt thermal treatment. J. Mater. Process. Technol. 2003, 141, 29-34.

12. Zhang, R.; Cao, Q.F.; Pang, S.X.; Wei, Y.; Liu, L. Dissolution kinetics of primary silicon in hypereutectic Al-Si melt. Sci. Technol. Adv. Mater. 2001, 2, 3-5.

13. Liu, X.F.; Wu, Y.Y.; Bian, X.F. The nucleation sites of primary Si in Al-Si alloys after addition of boron and phosphorus. J. Alloys Compd. 2005,391, 90-94.

14. Srivastava, V.C.; Mandal, R.K.; Oiha, S.N. Evolution of microstructure in spray formed Al-18\%Si alloy. Mater. Sci. Eng. 2004, 383, 14-20.

15. Chang, J.Y.; Moon, I.G.; Choi, C.S. Refinement of cast microstructure of hypereutectic Al-Si alloys through the addition of rare earth metals. J. Mater. Sci. 1998, 33, 5015-5023.

16. Chen, C.; Liu, Z.X.; Ren, B.; Wang, M.X.; Weng, Y.G.; Liu, Z.Y. Influences of complex modification of $\mathrm{P}$ and $\mathrm{RE}$ on microstructure and mechanical properties of hypereutectic Al-20Si alloy. Trans. Nonferrous Met. Soc. China 2007, 17, 301-306.

17. Xiong, B.Q.; Zhang, Y.G.; Wei, Q. The study of primary Si phase in spray forming hypereutectic Al-Si alloy. J. Mater. Process. Technol. 2003, 137, 183-186. 
18. Ho, C.R.; Cantor, B. Heterogeneous nucleation of solidification of $\mathrm{Si}$ in Al-Si and Al-Si-P alloys. Acta Met. Mater.1995, 43, 3231-3246.

19. Kumar,G.S.; Murty, B.S.; Chakraborty, M. Development of Al-Ti-C grain refiners and study of their grain refining efficiency on $\mathrm{Al}$ and $\mathrm{Al}-7 \mathrm{Si}$ alloy. J. Alloys Compd. 2005, 396, 143-150.

20. Yucel, B. Grain refining efficiency of Al-Ti-C alloys. J. Alloys Compd.2006, 422, 128-131.

21. Kumar, G.S.; Murty, B.S.; Chakraborty, M. Grain refinement response of LM25 alloy towards $\mathrm{Al}-\mathrm{Ti}-\mathrm{C}$ and Al-Ti-B grain refiners. J. Alloys Compd. 2009, 472, 112-120.

22. Li, Y.L.; Feng, H.K.; Cao, F.R.; Chen, Y.B.; Gong, L.Y. Effect of high density ultrasonic on the microstructure and refining property of Al-5Ti-0.25C grain refiner alloy. Mater. Sci. Eng. A 2008, 487, 518-523.

23. Liu, X.F.; Wang, Z.Q.; Zhang, Z.G.; Bian, X.F. The relationship between microstructures and refining performances of Al-Ti-C master alloys. Mater. Sci. Eng. A 2002, 332, 70-74.

24. Sagstad, T.; Bhondus, E. Master Alloy for Modification and Grain Refining of Hypoeutectic and Eutectic Al-Si Foundry Alloys. US6531092 B2, 11 March 2001.

25. Easton, M.; John, D. Grain refinement of aluminum alloys. Met. Mater. Trans. A 1999, 30, $1613-1623$.

26. Zhao, H.L.; Bai, H.L.; Wang, J.; Guan, S.K. Preparation of Al-Ti-C-Sr master alloys and their refining efficiency on A356 alloy. Mater. Character 2009, 60, 377-383.

27. Banerji, A.; Reif, W. Development of Al-Ti-C Grain Refiners containing TiC. Metall.Trans. A 1986, 17, 2127-2137.

28. López, V.H.; Scoles, A.; Kennedy, A.R. The thermal stability of TiC particlesin an Al-7 wt\%Si alloy. Mater. Sci. Eng. 2003, 356, 316-325.

29. Yu, L.N.; Liu, X.F. Ti transition zone on the interface between TiC and aluminum melt and its influence on melt viscosity. J. Mater. Process. Technol. 2007,182, 519-524.

30. Mohanty, P.S.; Gruzleski, J.E. Mechanism of grain refinement in aluminum. Acta Met. Mater. 1995, 43, 2001-2012.

31. Guzowski, M.M.; Sigworth, G.K.; Sentner, D.A. The role of boron in the grain refinement of aluminum with titanium. Met. Trans. A 1987, 18, 603-619.

32. Ma, H.T.; Li, J.G.; Zhang, B.Q. Research on crystal nuclei of aluminum alloy refined by Al-Ti-C master alloy. Heat Treat. Met. 1999, 10, 1-3.

33. Yang, Y.F.; Xu, C.L.; Wang, H.Y.; Liu, C.; Jiang, Q.C. Effect of $\mathrm{Y}_{2} \mathrm{O}_{3}$ on microstructure and mechanical properties of hypereutectic Al-20\%Si alloy. Trans. Nonferrous Met. Soc. China 2006, $16,1332-1335$.

34. Lee, H.S.; Yeo, J.S.; Hong, S.H.; Yoon, D.J.; Na, K.H. The fabrication process and mechanical properties of $\mathrm{SiC}_{\mathrm{p}} / \mathrm{Al}-\mathrm{Si}$ metal matrix composites for automobile air-conditioner compressor pistons. J. Mater. Process. Technol. 2001, 113, 202-208.

35. Ding, W.W.; Zhao, W.J.; Xia, T.D. Preparation of Al-Ti and Al-TiC grain refiners by thermal. Foundry Technol. 2008, 11, 1554-1558.

(C) 2014 by the authors; licensee MDPI, Basel, Switzerland. This article is an open access article distributed under the terms and conditions of the Creative Commons Attribution license (http://creativecommons.org/licenses/by/3.0/). 